\title{
Dynamic of phytoplankton assemblages, as a response in the change of Water Quality in Lake Ahémé (BENIN)
}

\author{
Olodo I. Y..$^{1, *}$, Abou Y. ${ }^{1}$, Kokou K. ${ }^{2}$ and Cocquyt C. ${ }^{3}$
}

\author{
${ }^{1}$ Laboratoire d'Ecologie et de Management des Ecosystèmes Aquatiques, Département de Zoology, Faculté des Sciences et Techniques, \\ Université d'Abomey-Calavi, Abomey-Calavi, PO Box 526, République du Bénin \\ ${ }^{2}$ Laboratoire de Botanique et d'Ecologie des Plantes, Faculté des Sciences, Université de Lomé, P. O. Box 1515, Lomé, Togo. \\ ${ }^{3}$ Research Department, Meise Botanic Garden, Meise, Belgium \\ *Corresponding author
}

\begin{abstract}
This study aims to assess seasonal and temporal changes in phytoplankton composition in Lake Ahémé. To achieve this, phytoplankton samples were collected in Lake Ahémé from September 2014 to September 2016. A total of 274 species were inventoried and the composition of algae includes Bacillariophyceae, Chlorophyceae, Cyanophyceae, Euglenophyceae, Conjugatophyceae, Trebouxiophyceae, Chrysophyceae, Dinophyceae, Xanthophyceae and Ulvophyceae. Bacillariophyceae were more abundant during the long wet season, the short dry season, and the long dry season, while Chlorophyceae dominated during the short wet season. The two-way analysis of variance (ANOVA) revealed significant seasonal variations in water physicochemical parameters such as conductivity, temperature, Total dissolved solids, pH, salinity, dissolved oxygen, turbidity, phosphates. Changes in phytoplankton structure were analyzed through similarity analysis (ANOSIM) and revealed that the heterogeneity observed in the spatial and seasonal distribution of phytoplankton of Lake Ahémé is linked with the dynamic of water inputs (freshwater, saltwater, nutrients). Redundancy analysis (RDA) revealed that phytoplankton community assemblages are mainly driven by two environmental gradients, one of anthropogenic origin, where the most influential factors were phosphates and DO. The second gradient is related to temperature, conductivity, and salinity.
\end{abstract}

Keywords-Dynamic, Heterogeneity, Phytoplankton, Pollution.

\section{INTRODUCTION}

Over the last few decades, wetland pollution is widely known to lead remarkable losses to human well-being and economic development consequences for communities, businesses, and countries [1]. Besides, the current population explosion mainly induces stress in aquatic ecosystems. Thus, human activities have often been reported as one of the main causes of stress observed in aquatic biodiversity especially, changes in diversity and abundance of phytoplankton. Phytoplankton is the basis of the aquatic food web and responds effectively to environmental variations that affect the biological activity and water quality [2].

Furthermore, eutrophication strongly limits the growth of fish species due to strong variations observed in the Physico-chemical parameters involved (nutrients, temperature, transparency, etc.) [3]. For example, dissolved oxygen at low concentrations causes fish mortality and the growth of environmentally harmful pathogenic microorganisms [4]. In addition to environmental variables, the most expressive of habitats modification are biological variables because of their high capacity to integrate information as an indicator of aquatic environmental degradation episodes [5]. However, the eutrophication of lakes, known as an ecological problem affecting many coastal ecosystems, hurts primary producers (phytoplankton) which are the first organisms affected [6]. Frequent fluctuations in orthophosphates and nitrogen concentrations in the aquatic environment affect the algal composition and biomass [7]. Phytoplankton growth is therefore dependent on the availability or otherwise of one of the key factors favoring its development [8]. Similarly, phytoplankton can react very quickly to environmental variations such as water temperature, transparency, and nutrients, which often leads to dramatic changes in their 
structure and dynamics [9]. Also, the phytoplankton compartment is characterized by assemblages of species of varying morphology and physiology (size, modes of nutrition, and reproduction) that are widely recognized as an important group in the assessment of aquatic environment [10].

In Benin, Lake Ahémé is subject to anthropogenic stress when classified as an area of international interest and part of Ramsar 1017 [11]. Because of its size, productivity, and different uses, it offers extraordinary benefits by providing people with ecosystem goods and services (tourism, fishing, drinking water, etc.). Unfortunately, Lake Ahémé is under increasing threat due to numerous human activities (inappropriate fishing techniques, wastewater discharges, intensive agriculture, etc.) [12]. The strong demographic pressure often reported in this lake leads to eutrophication [13] [14] [15] [4] [11]. These authors also highlighted the problem of the filling up of Lake Ahémé and the change in its hydrological regime. This influences the biological communities of the lake by contributing to changes in their structure (diversity, density, and biomass). Thus, it is important to understand the mechanisms that control the dynamics of these microalgae and to assess their diversity as well as the structure of the different assemblages. Therefore, based on the phytoplankton composition in Lake Ahémé, it is necessary to study the dynamic of the phytoplankton and to identify the environmental factors that contribute to this composition, for bioassessment and better management of its resources. According to [16], in ecological studies, it is difficult to measure the effect of biodiversity on community productivity in natural ecosystems based on the control of environmental gradients because of the large number of variables that influence diversity. Thus, an alternative is the use of multivariate methods to statistically detect and control the direct and indirect effects of diversity and environmental variables on ecosystem functions [17]. Moreover, multivariate statistics are effective and informative statistical methods used for determining the main mechanisms of change in species composition and linking them to physical, chemical, or to some extent to their biological characteristics of the ecosystems studied [18] [19].
The main objective of this paper was to study and use phytoplankton assemblages to monitor water quality in Lake Ahémé. The goal was to identify abiotic factors and assess their influence on the diversity and structure of Lake Ahémé's phytoplankton.

\section{MATERIALS AND METHODS}

\section{Physico-chemical and biological studies}

The study was conducted on Lake Ahémé (Figure 1) located in southern Benin (6이 $\left.6^{\circ} 40^{\prime \prime} \mathrm{N}, 1^{\circ} 55^{\prime \prime} 2^{\circ} 00^{\prime \prime} \mathrm{E}\right)$ with a surface area of $78 \mathrm{~km} 2$ during low-tide periods and $100 \mathrm{~km} 2$ during flood periods.

Water sampling was carried out for the study of Physicochemical parameters and phytoplankton during the four seasons of the year (SDS: short dry season; LDS: long dry season; SWS: the short wet season and LWS: long wet season). The basic physical parameters of the water, namely temperature, $\mathrm{pH}$, conductivity, salinity, total dissolved solids (TDS) and dissolved oxygen (DO), were measured in situ (at the 8 sampling sites S1 S2 S3 S4 S5 S6 S7 and S8) using the HANNA multi-sensor probe (HI9829). Water transparency (SDD) and water depth were determined by using a Secchi disc. Turbidity was determined in situ using a turbidimeter (Eutech instruments). Nutrients have been measured in the laboratory. To determine water nutrient levels (nitrates (NO3-), nitrites (NO2-), phosphates (PO43-), 1.5 L water samples were collected and kept cool in the dark in the laboratory. Ammonium, nitrate, nitrites, and phosphates were measured with the spectrophotometer respectively using the method with 4-aminobenzene sulfonamide, sodium salicylate, Nessler reagent, ammonium molybdate, and ascorbic acid, as described by [20].

Phytoplankton was sampled with plankton net mesh $20 \mu \mathrm{m}$ and treated in the lab before mounting on Bürker counting cell using light microscopy $(\times 400)$ and the Utermöhl method [21]. Phytoplankton were identified to the lowest practical taxonomic level according to the literature from [22] [23] [24] [25] [26] [27] [28] [29] [30]. 


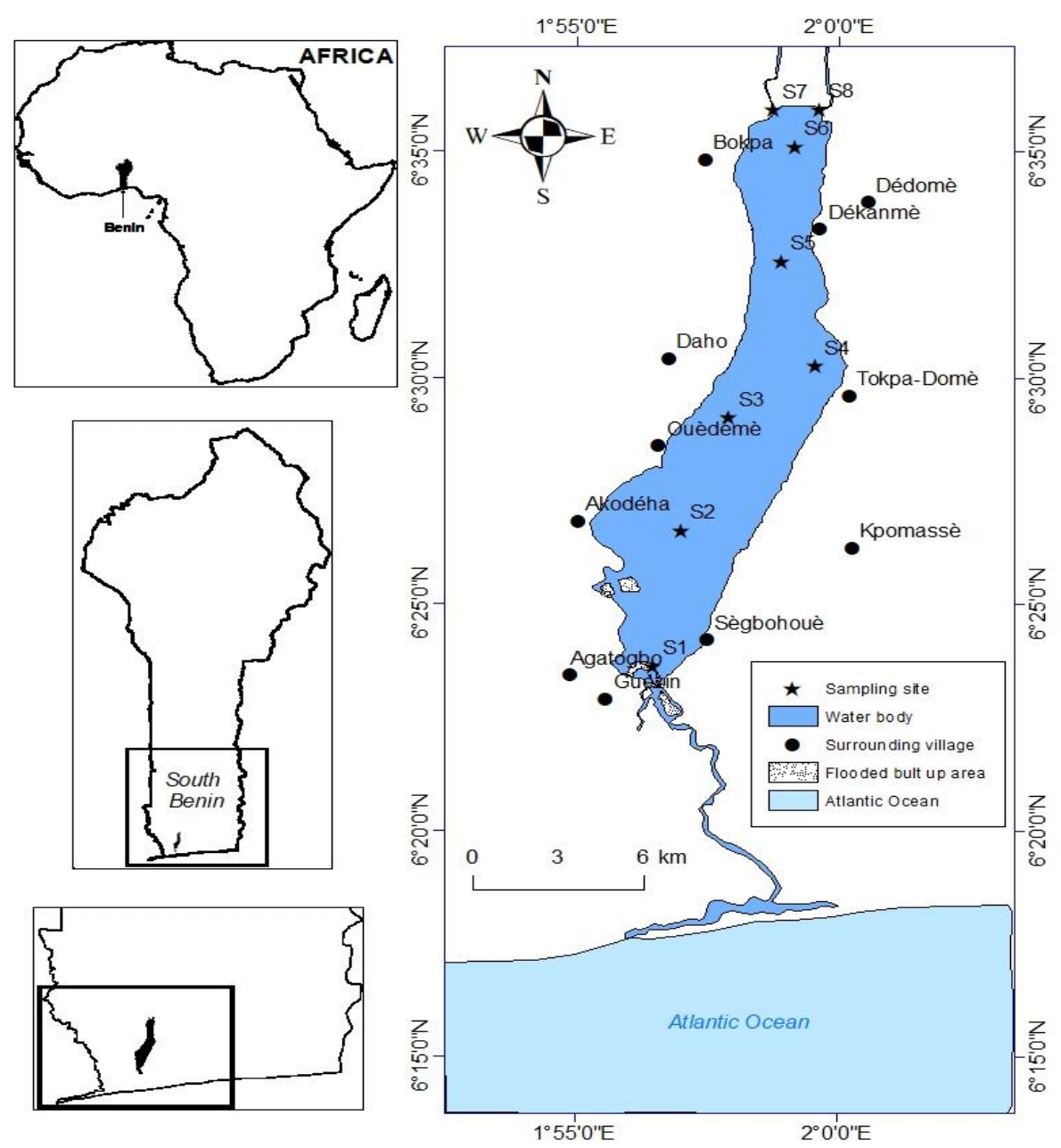

Fig.1: Lake Ahémé and sites locations

\section{Data treatment and analyses}

To study the spatio-temporal variation of water physicochemical characteristics in Lake Ahémé, two-factor analysis of variance (ANOVA) was carried out (followed by a post hoc Tukey's test) to test the effect of seasons and sites on the variation of physico-chemical water parameters. This two-way ANOVA has also tested the interaction between season and site, to see if the difference between sites depends on the seasons and vice versa.

The spatio-temporal patterns of the phytoplankton community have also been studied. To assess the degree of dissimilarity of the phytoplankton communities between the sites and the season, a non-metric multidimensional analysis (NMDS) based on Bray \& Curtis similarity measure [31] was performed. When the points are arranged in a continuum, such that they emerging together, this corresponds to sites in which species composition is similar. On the other hand, points that are far from those ranged together correspond to dissimilar sites. Stress levels of NMDS representation comprised between 0.1 and 0.25 indicate a satisfactory representation of the data. The analysis of similarity ANOSIM [32] has also been made based on [33] distance to test statistical differences in environmental and phytoplankton data among the samples (seasons and sites). The environmental data were $\log (\mathrm{x}+1)$ transformed before processing. The similarity percentage analysis (SIMPER) was applied to phytoplankton species abundance, to allow for indexing the taxa responsible for the variation of the structure. All the above-listed analyses were undertaken using Past (V 3.14) software.

To measure the relationship between phytoplankton community and environmental variables, we sought to reduce a large number of species to a reasonable number by first calculating the average abundance of each species over the sampling period. The deciles of the species abundance averages were then exploited to group the species into ten groups, as shown in Table 1. The first groups were grouping the species with low abundance 
while the last groups include species with high abundance. The species list and their different groups are illustrated in the annex (Table 5). Then, we performed a Redundancy Analysis (RDA) [34] on the abundance data of the groups obtained, elucidate their relationship with their environment. For data processing, the software CANOCO for Windows 4.5. was used.

Table 1 : Values of the deciles of mean abundance and name of the created groups.

\begin{tabular}{|l|l|}
\hline Decile of mean abundance & Group of species \\
\hline $8.33(10 \%)$ & Group1 \\
$16.67(20 \%)$ & Group2 \\
$20-42(30 \%)$ & Group3 \\
$50-58(40 \%)$ & Group4 \\
$62-117(50 \%)$ & Group5 \\
$125-200(60 \%)$ & Group6 \\
$208-375(70 \%)$ & Group7 \\
$379-992(80 \%)$ & Group8 \\
$1108-3850(90 \%)$ & Group9 \\
$3865-488910(100 \%)$ & Group 10 \\
\hline
\end{tabular}

\section{RESULTS}

\section{Physico-chemical characteristics}

Spatio-temporal variation of water physico-chemical characteristics in the Lake Ahémé
The physical and chemical features of the water in Lake Ahémé are characterized by a range of variations (Table 2). In this ecosystem, depth values ranged between $1.05 \mathrm{~m}$ in LDS and $1.91 \mathrm{~m}$ in LWS, with significantly different ( $p<0.05$ ) only in SDS compared to those of LDS and SWS. The SDD value recorded in LDS was not significantly different $(p>0.05)$ to the one of LWS with values varying between $0.48 \mathrm{~m}$ in SWS and $0.73 \mathrm{~m}$ in SDS. Turbidity varied between 28.65 NTU in LDS and 380.53 NTU in SWS. The temperature was significantly different from one season to another $(\mathrm{p}<0.05)$, with values ranging between $27.36^{\circ} \mathrm{C}$ in SDS and $29.83{ }^{\circ} \mathrm{C}$ inSWS, while the $\mathrm{pH}$ remains the same $(\mathrm{p}>0.05), 6.85$ in SWS and 7.47 in LDS. A significant difference was found for dissolved oxygen (DO) $(\mathrm{p}<0.05)$ from one season to another and ranged between $2.67 \mathrm{mg} / \mathrm{L}(0.09-2.90)$ in SWS and $4.09 \mathrm{mg} / \mathrm{L}$ (2.84- 8.14) in LDS. A significant difference $(\mathrm{p}<0.05)$, is observed in TDS variations and values are ranged between $0.46 \mathrm{~g} / \mathrm{L}$ in SWS and $15 \mathrm{~g} / \mathrm{Lin}$ LDS. Salinity and conductivity showed significant difference among the seasons $(\mathrm{p}<0.05)$ with values ranged between 0.19PSU in SWS and 18.53PSU in LDS for salinity and0.46 $\mathrm{mS} / \mathrm{cm}$ in SWS and $29.43 \mathrm{mS} / \mathrm{cm}$ in LDS. Nitrates showed significant difference in SWS $(p<0.05)$ with values ranged from $25.94 \mu \mathrm{g} / \mathrm{L}$ in LDS to 459.92 $\mu \mathrm{g} / \mathrm{L}$ in SDS. Nitrite and nitrate were significantly different in LDS $(\mathrm{p}<0.05)$. Their values varied between 19.74-71.50 $\mu \mathrm{g} / \mathrm{L}$ and 25.94-459.92 $\mu \mathrm{g} / \mathrm{L}$,respectively. There was also a significant difference $(p<0.05)$ in phosphate variations with values varied between 18.18 $\mu \mathrm{g} / \mathrm{L}$ in LWS and 546.23 $\mu \mathrm{g} / \mathrm{L}$ in SWS.

Table 2 : Water quality parameters in Lake Ahémé. LDS: long dry season, LWS: long wet season, SDS: short dry season, SWS: short wet season.

\begin{tabular}{|c|c|c|c|c|}
\hline Variable & LDS & LWS & SDS & SWS \\
\hline $\operatorname{Depth}(\mathrm{m})$ & $1.05^{\mathrm{a}}$ & $1.91^{\mathrm{c}}$ & $1.15^{\mathrm{ab}}$ & $1.68^{b}$ \\
\hline SDD (m) & $0.67^{b}$ & $0.54^{\mathrm{a}}$ & $0.73^{c}$ & $0.48^{\mathrm{a}}$ \\
\hline Temperature $\left({ }^{\circ} \mathrm{C}\right)$ & $27.71^{\mathrm{c}}$ & $29.15^{\mathrm{a}}$ & $27.36^{\mathrm{b}}$ & $29.83^{d}$ \\
\hline $\mathrm{DO}(\mathrm{mg} / \mathrm{L})$ & $4.09^{\mathrm{b}}$ & $3.06^{\mathrm{c}}$ & $3.53^{\mathrm{d}}$ & $2.67^{\mathrm{a}}$ \\
\hline $\mathrm{pH}$ & 7.47 & 7.36 & 7.15 & 6.85 \\
\hline Salinity (PSU) & $18.53^{\mathrm{d}}$ & $3.10^{\mathrm{b}}$ & $13.49^{c}$ & $0.19^{\mathrm{a}}$ \\
\hline Conductivity ( $\mathrm{ms} / \mathrm{cm})$ & $29.43^{\mathrm{d}}$ & $5.46^{\mathrm{b}}$ & $25.09^{c}$ & $0.46^{\mathrm{a}}$ \\
\hline TDS (g/L) & $15.00^{\mathrm{d}}$ & $2.78^{b}$ & $11.54^{\mathrm{c}}$ & $0.46^{\mathrm{a}}$ \\
\hline Nitrite $(\mu \mathrm{g} / \mathrm{L})$ & $19.74^{\mathrm{a}}$ & $25.37^{\mathrm{a}}$ & $23.29^{\mathrm{b}}$ & $71.50^{\mathrm{a}}$ \\
\hline Nitrate $(\mu \mathrm{g} / \mathrm{L})$ & $25.94^{\mathrm{a}}$ & $48.00^{\mathrm{a}}$ & $459.92^{\mathrm{a}}$ & $255.51^{b}$ \\
\hline Phosphate $(\mu \mathrm{g} / \mathrm{L})$ & $50.09^{b}$ & $18.18^{\mathrm{a}}$ & $60.11^{\mathrm{c}}$ & $546.23^{\mathrm{d}}$ \\
\hline
\end{tabular}




$\begin{array}{lllll}\text { Turbidity (NTU) } & 28.65^{\mathrm{a}} & 369.95^{\mathrm{b}} & 344.38^{\mathrm{c}} & 380.53^{\mathrm{d}}\end{array}$

$\mathrm{a}, \mathrm{b}, \mathrm{c}, \mathrm{d}$ for each parameter, the same-letter means as the exponents are not significantly different $(\mathrm{p}>0.05)$. The letters a. $\mathrm{b}$. $\mathrm{c}$ or $\mathrm{d}$ denote the significant difference between seasons and sites (multiple pair comparison): pairs with different letters (2 or 3 alphabetical letters together) do not differ significantly $(\mathrm{P} \leq 0.05)$.

\section{Assemblages of the Phytoplankton community}

nMDS showed that the distribution of the phytoplankton within sites, mostly in sites $4,5,7$, and 8 is heterogeneous (Figure 2). The same trend is noticed between the communities within the seasons. Besides, the stress value
(0.2289) revealed that the representation of the sites is satisfactory. The sites 4, 5, 6, 1 seems to be similar to each other, while LDS seemed to be similar to LWS and SWS to LDS.
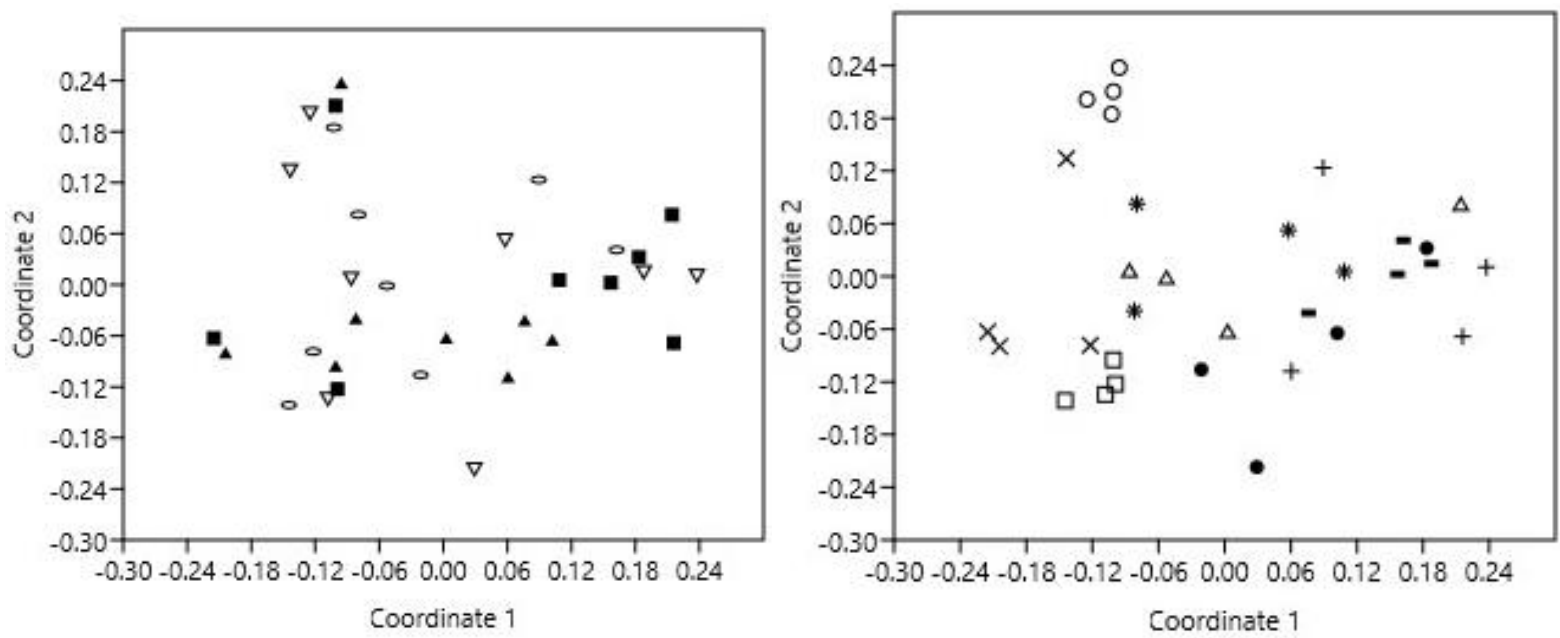

Fig.2: $n$-MDS diagram $(n=24$, stress $=0.23)$ showing the similarity of species composition among sampling sites indicated by the distances between dots.

Oval : LDS ; Inv. triangle : LWS ; Fill triangle : SDS ; Fill square : SWS. Dot S1 ; Plus : S2 ; Square : S3 ; X : S4 ; O : S5 ; Star : S6 ; Triangle : S7 ; Dash : S8.

According to nMDS and ANOSIM, the taxonomic composition of phytoplankton strongly differed both within sites and seasons.

The two-way ANOSIM (Table 3) showed significant differences among the sites $(\mathrm{R}=0.36344, \mathrm{p}=0.0006)$ and across the seasons $(R=0.25306, p=0.0184)$ in Lake Ahémé. The post-hoc pairwise comparison also revealed significant differences within all sites between seasons mainly observed in LWS and SDS with a high dissimilarity
(96.04\%). However, the phytoplankton communities of SWS and LDS did not differ from each other $(\mathrm{R}=0.159$; $\mathrm{p}=0.0618)$. The results of the pairwise comparison (ANOSIM) showed that there were significant differences of phytoplankton communities in twenty of the twentyeight scenarios with particular attention given to the following scenarios: $\mathrm{S} 1$ vs $\mathrm{S} 5(\mathrm{R}=1, \mathrm{p}=0.0279)$; $\mathrm{S} 3$ vs S5 $(\mathrm{R}=1 ; \mathrm{p}=0.0298) ; \mathrm{S} 3$ vs $\mathrm{S} 8(\mathrm{R}=1 ; \mathrm{p}=0.0252)$ and $\mathrm{S} 5$ vs $\mathrm{S} 8$ $(\mathrm{R}=1 ; \mathrm{p}=0.0265)$.

Table 3 : ANOSIM (Two-way) of Phytoplankton assemblages and similarity percentage (SIMPER) among seasons and sites.

Only significant differences $(p<0.05)$ are mentionned. $P$ is a probability and $R$ is a statistical value of the ANOSIM test.

LDS: long dry season, LWS: long wet season, SDS: short dry season, SWS: short wet season. Si= Site i. S1: Site 1; S2: Site 2; S3: Site 3; S4: Site 4; S5: Site 5; S6: Site 6; S7: Site 7; S8: Site 8.

\begin{tabular}{llll}
\hline Pairwise comparison & Dissimilarity $\%$ & $\mathrm{R}$ & $\mathrm{P}$ \\
\hline Season Factor & & & \\
\hline SWS vs SDS & 92.98 & 0.6027 & 0.0011 \\
SWS vs SWS & 94.46 & 0.6646 & $\mathbf{0 . 0 0 0 3}$
\end{tabular}


International Journal of Environment, Agriculture and Biotechnology, 5(3) May-Jun, 2020 / Available: https://ijeab.com/

\begin{tabular}{|c|c|c|c|}
\hline SDS vs SWS & 92.59 & 0.6613 & 0.0005 \\
\hline SDS vs LDS & 92.55 & 0.5273 & 0.0015 \\
\hline LWS vs LDS & 96.04 & 0.7868 & 0.0003 \\
\hline Average & 92.15 & 0.5622 & 0.0001 \\
\hline \multicolumn{4}{|l|}{ Site Factor } \\
\hline $\mathrm{S} 1$ vs $\mathrm{S} 3$ & 94.38 & 0.8438 & 0.0259 \\
\hline $\mathrm{S} 1$ vs $\mathrm{S} 4$ & 96.59 & 0.9167 & 0.0293 \\
\hline S1 vs S5 & 98.13 & 1 & 0.0279 \\
\hline $\mathrm{S} 2$ vs $\mathrm{S} 3$ & 97.47 & 0.9896 & 0.0298 \\
\hline $\mathrm{S} 2$ vs S4 & 95.73 & 0.8646 & 0.0307 \\
\hline S2 vs S5 & 93.67 & 0.8021 & 0.03 \\
\hline S2 vs S6 & 90.6 & 0.6667 & 0,026 \\
\hline $\mathrm{S} 3$ vs S4 & 86.06 & 0.3854 & 0.0295 \\
\hline S3 vs S5 & 97.68 & 1 & 0.0298 \\
\hline S3 vs S6 & 93.29 & 0.9167 & 0.0284 \\
\hline $\mathrm{S} 3$ vs S7 & 91.49 & 0.5417 & 0.0281 \\
\hline $\mathrm{S} 3$ vs $\mathrm{S} 8$ & 96.49 & 1 & 0.0252 \\
\hline S4 vs S5 & 85.46 & 0.7396 & 0.0278 \\
\hline S4 vs S6 & 93.94 & 0.7813 & 0.0307 \\
\hline S4 vs S7 & 92.6 & 0.3333 & 0.0265 \\
\hline S4 vs S8 & 97.25 & 0.9896 & 0.0269 \\
\hline S5 vs S6 & 91.05 & 0,9167 & 0.0291 \\
\hline S5 vs S7 & 96.45 & 0,8646 & 0.0294 \\
\hline S5 vs S8 & 98.88 & 1 & 0.0265 \\
\hline S6 vs S8 & 85.18 & 0.6458 & 0.0294 \\
\hline Average & 91.34 & 0.7013 & 0.0001 \\
\hline
\end{tabular}

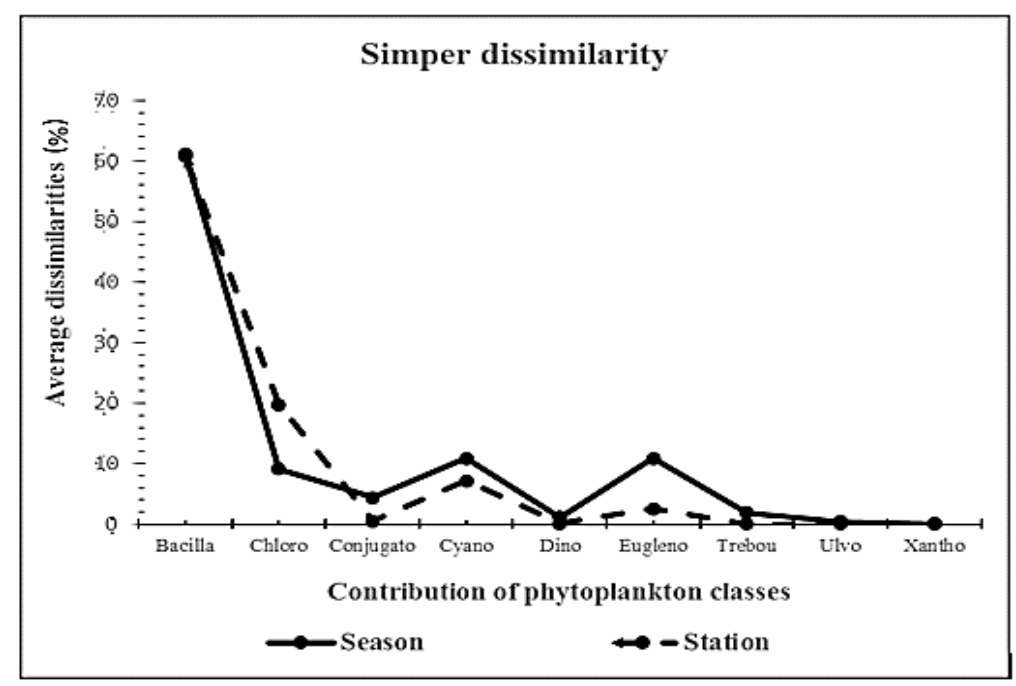

Fig.3: Contribution of the phytoplankton classes to the spatial and temporal assemblages of phytoplankton of Lake Ahémé. 
Bacilla $=$ Bacillariophyceae, Chloro $=$ Chlorophyceae, Conjugato $=$ Conjugatophyceae, $C y a n o=C y a n o p h y c e a e, D i n o=$ Dinophyceae, Eugleno= Euglenophyceae, Trebou= Trebouxiophyceae, Ulvo= Ulvophyceae, $\mathrm{Xantho=Xanthophyceae}$.

The SIMPER procedure identified four taxa that contributed the most to the differences in the assemblages (Figure 3), including thirty species of Bacillariophyceae (in which Entomoneis paludosa, Surirella robusta, Melosira sp., Cerataulina bicornis, Entomoneis alata, Nitzschia sp., Aulacoseira granulata, Cyclotella sp., Iconnella capronii, Coscinodiscus sp., Navicula sp. and Surirella sp.), four species of Cyanophyceae (Lyngbya sp., Mycrocystis sp., Synechococcus sp. and Oscillatoria sp.), two species of Chlorophyceae (Eudorina elegans and Pandorina morum) and one species of Euglenophyceae (Phacus contortus).

The average dissimilarity of Bacillariophyceae (Figure 3) was very high, amounting to $61.22 \%$ through the seasons and of $60.87 \%$ for the sites. When Chlorophyceae appeared to better contribute to the dissimilarity of assemblages through sites than through seasons, Bacillariophyceae, Cyanophyceae, Euglenophyceae, Conjugatophyceae and Trebouxiophyceae appeared to be more expressive to the dissimilarity through the seasons. Bacillariophyceae species such as Entomoneis paludosa, Aulacoseira sp., Gyrosigma sp., Surirella sp., Coscoinodiscus lacustris, Coscinodiscus sp., Gyrosigma accuminatum, Gyrosigma fasciola, Aulacoseira granulata, Nitzschia sp., Nitzschia linearis, Nitzschia reversa, Nitzschia closterium, Cyclotella sp. and Stephanodiscus rotula were mainly responsible to the variation of the phytoplankton assemblages at all the sites. However, taxa of Chlorophyceae (Eudorina elegans) and Cyanophyceae (Microcystis sp.) also characterized site S1, Cyanophyceae (Lyngbya limnetica, Planktolyngbya sp.) characterized sites S4 and S6; Chlorophyceae (Eudorina elegans, Pandorina morum) characterized sites S5, S7, and S8; Cyanophyceae (Anabaena sp., Synechococcus sp., Lyngbya sp.), Chlorophyceae (Oedogonium sp., Eudorina elegans) and Euglenophyceae (Euglena sp.) characterized sites S2 and S3. Based on seasons, the distribution of phytoplankton assemblages is mostly characterized by only Bacillariophyceae (Entomoneis paludosa, Aulacoseira granulata, Iconella capronii, Navicula sp.) in LWS and by Bacillariophyceae (Aulacoseira sp and Cerataulina bicornis) and Chlorophyceae (Eudorina elegans) in SWS while the dry season is characterized by Bacillariophyceae (Entomoneis paludosa, Surirella robusta, Melosira sp., Nitzschia sp.,
Cyclotella sp. and Coscinodiscus sp.), Chlorophyceae (Eudorina elegans) and Cyanophyceae (Lyngbya sp., Microcystis sp., Planktolyngbya sp.).

\section{Relationship between phytoplankton and environmental variables}

The RDA results showed that the first two components accounted for $86.1 \%$ of the taxon-environment relationship whilst also accounting for $43.9 \%$ of the variance in the phytoplankton taxon, with correlation coefficients of 0.873 and 0.736 for first and second axis, respectively (Table 4). Based on the environmental input variables listed in table 2 , forward screening revealed that DO, phosphate, salinity, conductivity, and temperature were important to describe trends in the occurrence and abundance of phytoplankton taxa in Lake Ahémé. Figure 4 shows that phosphate, salinity, and conductivity are explained by the first RDA while DO and temperature are explained by the second RDA axis. Also, groups 1, 2, 3, 4, 5, 6, 7, 8, and 9 are observed with low values of phosphates, salinity, and conductivity, as opposed to group 10 which are observed when these values are high. Groups 2,3,5,7 and 8 are most commonly observed when the temperature is high and the DO values are very low. This last characteristic seems to separate them from groups $1,4,5,6$, and 9 which are observed with average values of DO. As for group 10, it is especially observed when the values of phosphates, salinity, conductivity, and temperature are generally high but with low values of DO. Moreover, three categories of groups were observed and characterized by a specifically abiotic factor. The first category that is characterized by high temperature, high conductivity, and high rates of phosphates include essentially Bacillariophyceae, Chlorophyceae, Cyanophyceae, and Euglenophyceae. The second and third categories shared the same composition of taxa (Bacillariophyceae, Cyanophyceae, Chlorophyceae, Conjugatophyceae, Dinophyceae, Euglenophyceae, Ulvophyceae) except for Xanthophyceae and Trebouxyophyceae included respectively in each of these categories. Besides, the second category is characterized by low salinity, low phosphates and high DO levels, while the third category is characterized by the same variations in salinity and phosphate as the previous categories but with very low DO levels. 
International Journal of Environment, Agriculture and Biotechnology, 5(3)

May-Jun, 2020 / Available: https://ijeab.com/

Table 4 : Synthesis statistics of RDA outputs for individual and interactive relationships between species and environment in Lake Ahémé.

\begin{tabular}{lllll}
\hline & \multicolumn{2}{l}{ RDA axis } & & \\
\cline { 2 - 5 } Variables & 1 & 2 & 3 & 4 \\
\hline Eigenvalues & 0.392 & 0.047 & 0.037 & 0.027 \\
Species-environment correlations & 0.873 & 0.736 & 0.706 & 0.603 \\
Cumulative percentage variance & & & 50.3 \\
$\quad \begin{array}{l}\text { of species data } \\
\quad \text { of species-environment relation }\end{array}$ & 39.2 & 43.9 & 47.7 & 98.6 \\
\hline
\end{tabular}

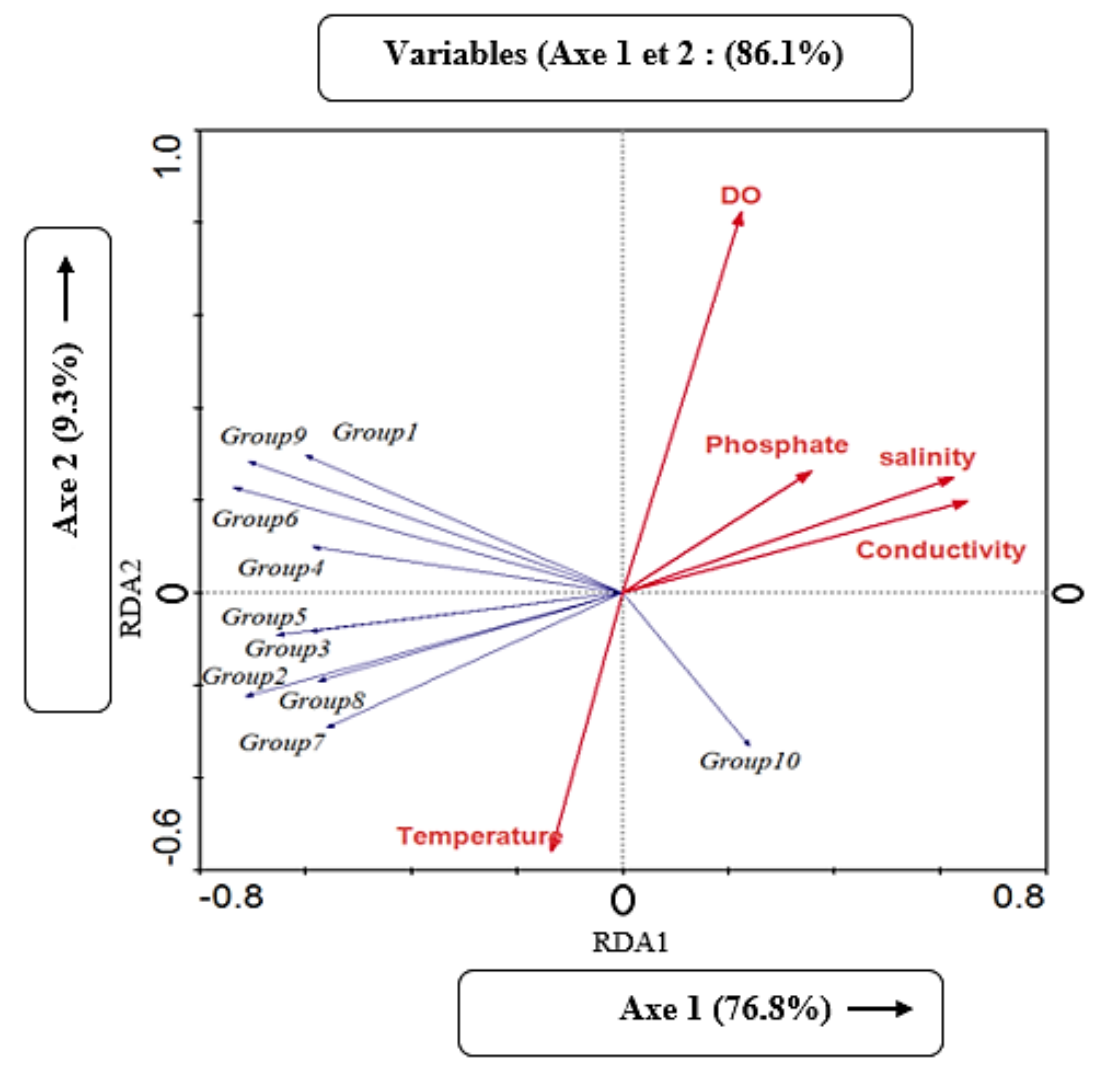

Fig.4: Diagram of RDA for physical and chemical variables (red segment) and phytoplankton groups (blue segment) during the four seasons in Lake Ahémé.

\section{DISCUSSION}

In general, environmental conditions in Lake Ahémé experienced seasonal fluctuations during the study period. The values obtained for the depth (1.05-1.91 m) are very similar to those obtained by [35] and [13] (0-2.5 $\mathrm{m}$ and 0 $2.35 \mathrm{~m}$ ) respectively, in the same ecosystem. Transparency values are low compared to those obtained by [36] in the same lake. Conversely, turbidity is relatively high (28.65$380.53 \mathrm{NTU}$ ) and this is due to precipitation which, following rainwater runoff, contributes to the loading of water bodies with various suspended solids such as silt, clay, organic and inorganic matter, etc. These values are higher than those obtained by [4] (75-98 NTU) in the same ecosystem. This divergence is believed to be due to the influence of human activities, which is becoming more and more pronounced in this ecosystem. However, the values obtained for temperature $\left(27.36^{\circ} \mathrm{C}-29.83^{\circ} \mathrm{C}\right)$ are consistent with those reported by [35] and [4]. Dissolved oxygen, with values between $2.67 \mathrm{mg} / \mathrm{L}$ and $4.09 \mathrm{mg} / \mathrm{L}$, is consistent with the variations obtained by [4] for the same parameter. According to [37], water with a dissolved 
oxygen content of less than $3 \mathrm{mg} / \mathrm{L}$ is classified as polluted. The low oxygen levels were recorded during the short wet season and show that Lake Ahémé is polluted during this period. Also, these low values indicate a high demand for dissolved oxygen in the decomposition process of organic matter. This results in deoxygenation of the environment, which leads to disturbances (anoxia/asphyxia) at the lake level [15]. Furthermore, salinity, conductivity and total dissolved solids evolved according to the same trends during the study. [4], obtained low values compared to those recorded in this study. This could be linked to the hydrodynamics of the environment (exchanges with the marine environment) which affect the balance of biocenosis, now selective. In so doing, the species group together in assemblages and are dominated by marine and estuarine affinity species [38]. The values of nitrates $(25.94-459.92 \mu \mathrm{g} / \mathrm{L})$, nitrites $(19.74-71.50 \mu \mathrm{g} / \mathrm{L})$ and orthophosphates $(18.18-546.23 \mu \mathrm{g} / \mathrm{L})$ observed are very high compared to those recorded by [39] in the Adzopé water body in Côte d'Ivoire. These nitrogen and phosphorus compounds, which are increasingly induced in large quantities in aquatic environments by human activities, cause blooms of phytoplankton organisms and consequently eutrophication.

During the study period, the highest phytoplankton density was recorded in the long wet season (LWS) while the lowest diversity was obtained during the short wet season (SWS). These results are in accordance with those of [40] which found high phytoplankton density in the rainy season in the Lake Bia in Côte d'Ivoire. In contrast [10] and [41] recorded respectively in Lake Taabo (Côte d'Ivoire) and the Douala Estuary (Cameroun), the lowest phytoplankton diversity in the rainy season. This difference is the result of environmental conditions that vary in each habitat. Besides, the phytoplankton community in Lake Ahémé showed significant heterogeneity in their assemblages. This can be explained by the different water parameters at each site and by the ecological flexibility of the species [42] Moreover, it can be seen from similarities analysis (ANOSIM), that seasons have a large effect on the distribution and composition of the phytoplankton community. As a consequence, SIMPER revealed that species such as Cerataulina bicornis, Surirella sp, Entomoneis alata, Entomoneis paludosa, Iconella capronii, Stephanodiscus rotula, Coscinodiscus sp., Nitschia linearis and Nitzschia sigma for the Bacillariophyceae, Eudorina elegans, Pandorina morum and Phacotus lenticularis for the Chlorophyceae, Synechococcus sp. and Planktolyngbya sp. for the Cyanophyceae are the major taxa characterizing the observed heterogeneity in Lake Ahémé. However, several factors may explain the observed dissimilarity in the phytoplankton community in Lake Ahémé. Thus, traditional fishing called "acadjas" leads to the siltation of Lake Ahémé [14] [15] and contributes to the disruption of its ecological balance, then having harmful effects on biodiversity. Besides, the intrusion of marine waters during high tide [12] could also explain this variability.

Similarly, weather conditions, thermostability and geographic distribution are key factors in explaining the dynamics of phytoplankton in aquatic ecosystems [43]. In SWS, the frequency of precipitation and the water level in the reservoir contributed to the dominance of the group of Chlorophyceae. The increase in water levels in the flooded areas of the lake has induced nutrient transport and consequently the effects of biogeochemical cycles and phytoplankton biomass [44].

Finally, changes in the phytoplankton biomass of Lake Ahémé are mainly induced by human activities, in the same way as the hydrological properties that control the variation and distribution of nutrients in the lake. Abiotic factors play a fundamental role in the organization of aquatic life. Depending on the season, these factors undergo fluctuations that induce changes in water levels. According to [45], the environmental factors most recognized as regulators of phytoplankton structure are physical (mixing of water masses, light, temperature, turbulence and salinity) and chemical (nutrients). In coastal ecosystems, changes in composition and structure of the phytoplankton compartment are generally observed in space and time due to abiotic gradients and grazing intensity [46] [47].

The phytoplankton structure in Lake Ahémé is guided by water quality variables such as temperature, DO, phosphates, salinity and conductivity, which best explains their spatial and temporal dynamics. The synthesis resulting from the analysis of the RDA leads us to question the taxonomic composition of each of these assemblages. As a result, the phytoplanktonic composition of the tenth group consisting of Bacillariophyceae, Chlorophyceae, Cyanophyceae and Euglenophyceae is due to high temperatures, high conductivity and high phosphate levels. Besides, the diatom Entomoneis paludosa, which is the most abundant species in this study, is detected by high temperature, high conductivity and high phosphate levels These results are consistent with those of [48] and [49] who found that Entomoneis paludosa is an epipelic diatom that grows in rivers with high salinity and high electrolyte concentrations. Bacillariophyceae, Cyanophyceae, Euglenophyceae, Euglenophyceae and Dinophyceae are known in the literature as indicators of pollution [50] [51]. However, their occurrence and dynamic in Lake Ahémé are driven by phosphates, the key nutrient for phytoplankton productivity in Lake Ahémé. 


\section{CONCLUSION}

The purpose of this study was to examine phytoplankton response to environmental changes in Lake Ahémé. Different ecological factors influenced phytoplankton abundance and structure, such as phosphorus, which was very important in the abundance of the Bacillariophyceae class. Several algal assemblages over the seasons and between sites indicate, to some extent, a type of water quality. Changes in water quality of Lake Ahémé were observed throughout the study period, inducing variations in phytoplankton assemblages. Thus, some environmental gradients could be predicted by the presence of certain algae species and the preferences and/or tolerances of habitat related to specific environmental conditions.

\section{ACKNOWLEDGMENT}

The authors would like to thank the Organization for Women in Science for the Developing World (OWSD) and the Belgian National Focal Point of the Global Taxonomy Initiative (CEBioS programme of the Royal Belgian Institute of Natural Sciences) for their help and support for this study.

\section{REFERENCES}

[1] Smith, M.E., Manoylov, K.M. (2013). Changes in Diatom Biodiversity in Lake Sinclair ,Baldwin County, Georgia, USA. J. Water Resour. Prot, 5, 732-742.

[2] Hamilton, P. B., Lavoie, I. \& Poulin, M. (2012). Spatial, seasonal and inter-annual variability in environmental characteristics and phytoplankton standing stock of the temperate, lowland Rideau River, Ontario, Canada. - River Research and Applications, 28: 1551-1566.

[3] Benoît-Chabot, V. (2014). Les facteurs de sélection des bioindicateurs de la qualité des écosystèmes aquatiques: élaboration d'un outil d'aide à la décision. Université de Sherbrooke.

[4] Dèdjiho, A., Mama, D., Tomètin, L., Nougbodé, I., Sohounhloué, D., Boukari, M. (2013). Évaluation de la qualité physico-chimique de certains tributaires d'eaux usées du lac Ahémé au Bénin. J. Appl. Biosci, 70, 5608-5616.

[5] Nyakoojo, C., Byarujali, S.M. (2010). Temporal distribution of phytoplankton in Lake Nyamusingiri in the Albertine Rift Valley, Uganda. Afr. J. Ecol, 48, 865-870.

[6] Chikhaoui, M.A., Hlaili, A.S., Mabrouk, H.H. (2008). Réponses saisonnières du phytoplancton aux rapports d'enrichissements N:Si:P dans la lagune de Bizerte (SudOuest de la Méditerranée). Comptes Rendus - Biol, 331, 389-408.

[7] Farahani, F., Korehi, H., Mollakarami. S., Shandari, S., Zaferani, S. G., Shashm, Z. M.(2006). Phytoplankton diversity and nutrients at the Jajerood River in Iran Pak. Journal of Biological Science, 9: 1787-1790.
[8] Baek, S.H., Kim, D., Son, M., Yun, S.M., Kim, Y.O. (2015). Seasonal distribution of phytoplankton assemblages and nutrient-enriched bioassays as indicators of nutrient limitation of phytoplankton growth in Gwangyang Bay, Korea. Estuar. Coast. Shelf Sci, 163, 265-278.

[9] Pinckney, J.L., Paerl, H.W., Tester, P., Richardson, T.L. (2001). The Role of Nutrient Loading and Eutrophication in Estuarine Ecology. Environmental Health Perspectives. 109(5), 699-706.

[10] Groga, N., Ouattara, A., Koulibaly, A., Dauta, A., Amblard, C., Laffaille, P., Gourene, G. (2014). Dynamic and structure of phytoplankton community and environment in the lake Taabo (Côte d'Ivoire). Int. Res. J. Public Environ. Heal, 1, $70-86$.

[11] Dedjiho, C.A., Alassane, A., Chouti, W., Sagbo, E., Changotade, O., Mama, D., Boukari, M., Sohounhloue, D. (2014). Negative Impacts of the Practices of Acadjas on the Aheme Lake in Benin. Journal of Environmental Protection, 5, 301-309.

[12] Amoussou, E., 2004. Systèmes traditionnels de gestion durable du lac Ahémé au Bénin,https://www.researchgate.net/publication/237266059.

[13] Amoussou, E. (2010). Variabilité pluviométrique et dynamique hydro-sédimentaire $\mathrm{du}$ bassin versant $\mathrm{du}$ complexe fluvio-lagunaire Mono-Ahémé-Couffo (Afrique de l'Ouest ). PhD Thesis, Histoire. Université de Bourgogne, Français. 〈NNT : 2010DIJOL001〉. 〈tel-00493898v2> HAL.

[14] Badahoui, A., Fiogbe, E.D., Boko, M. (2010). Les causes de la dégradation du lac Ahémé et ses chenaux. Int. J. Biol. Chem. Sci, 4, 882-897.

[15] Mama, D. (2010). Méthodologie et résultats du diagnostic de l'eutrophisation du lac Nokoue (Bénin). Thèse de Doctorat. Université d'Abomey-Calavi.

[16] Wardle, D.A. (2001). No observational evidence for diversity enhancing productivity in Mediterranean shrublands. Oecologia 129:620-621.

[17] Kahmen, A., Perner, J., Audorff, V., Weisser, W., Buchmann, N. (2005). Effects of plant diversity, community composition and environmental parameters on productivity in montane European grasslands. Oecologia, 142, 606-615.

[18] Stevenson, R.J., Smol, J.P. (1999). Use of algae in environmental assessments, Freshwater Algae of North America: Ecology and Classification. Elsevier Inc. doi:10.1016/B978-0-12-741550-5.50024-6

[19] Cáceres, C., Rivera, A., González, S., Anadón, R. (2016). Phytoplankton community structure and dynamics in the North Atlantic subtropical gyre. Prog. Oceanogr, doi:10.1016/j.pocean.2016.12.003

[20] Rodier, J., Legube, B., Merlet, N. (2009). Analyse de l'eau. 9ème edition. Dunod: Paris, France. Rosenberg.

[21] Utermöhl, H. (1958). Zur Vervollkommnung der quantitativen Phytoplankton Methodik. Mitt Int Ver Theor Angew Limnol, 9:1-39.

[22] Bourrelly, P. (1968). Les algues d'eau douce. I. Les algues jaunes et brunes [Freshwater Algae. I. Yellow Algae and Brown Algae]. Paris: Boubée.

[23] Bourrelly P. (1972). (Tome I) - les algues d'eau douces : 
initiation à la systématique- les algues vertes. Édition N. Boubée et Cie.572p.

[24] Bourrelly P. (1981). (Tome II) - les algues d'eau douces : initiation à la systématique- les algues jaunes et brunes. Édition N. Boubée et Cie.517p.

[25] ILtIS, A. (1980). Les algues. Flore et Faune aquatiques de l'Afrique sahelo-soudanienne. J.R. Durand et C. Levêque (éditeurs), ORStOM; t1, 9-61.

[26] Barsanti, L., Gualtieri, P. (2006). Algae: Anatomy, Biochemistry, and Biotechnology, CRC. ed.

[27] Rumeau A. \& Coste M. (1988). Initiation à la systématique des diatomées d'eau douce. Pour l'utilisation pratique d'un indice diatomique générique. Bulletin Français de Pêche et de Pisciculture, 309 : 1-69.

[28] Compère, P. (1967). "Algues du Sahara et de la région du Lac Tchad [Algae from the Sahara and Lake Chad Region]." Bulletin du Jardin Botanique National de Belgique, 37: 109288.

[29] Rodriguez, S., Vergon, J.-P. (1996). Guide pratique de détermination générique des algues macroscopiques d'eau douce, Ministère de l'Environnement - DIREN FrancheComté, Besançon, 110 p.

[30] Couté, A., \& Bernard, C. (2001). Les cyanobactéries toxiques. Toxines d'algues dans l'alimentation, 21-37.

[31] Warwick, R.M., Clarke, K.R. (1991). A comparison of some methods for analysing changes in benthic community structure. J. Mar. Biol. Assoc, 71, 225-244.

[32] Clarke, K., Green, R. (1988). Statistical design and analysis for a "biological effects" study. Mar. Ecol. Prog. Ser, 46, 213-226.

[33] Bray, J. R. \& Curtis, J. T. (1957). An ordination of upland forest communities of southern Wisconsin. Ecological Monographs, 27: 325-349

[34] ter Braak, C. J. and Smilauer, P. (2002). CANOCO Reference Manual and CanoDraw for Windows User's Guide: Software for Canonical Community Ordination (version 4.5). Microcomputer Power, Ithaca, NY, USA, 500 pp.

[35] Oyédé, L.M., Lang, J., Tsawlassou, G. (1988). Un exemple de sédimentation biodétritique Holocène en climat tropical humide : le lac Ahémé (Bénin Afrique de l'Ouest). Journal of African Earth Sciences, 7(5/6): 835-855.

[36] Maslin, J.-L. \& Bouvet, Y. (1986) : Le lac Ahémé (Bénin): Présentation du milieu, caractéristiques mésologiques, nature des fonds et distribution des peuplements malacologiques. Oikos, 46: 192-202.

[37] Beaux, J. F (1998). L'environnement repères pratiques. Nathan, ISBN 209-18243-3,. 64-71.

[38] Villanueva, M.S. (2004). Biodiversité et relations trophiques dans quelques milieux estuariens et lagunaires de l'Afrique de l'ouest: adaptations aux pressions environnementales, Thèse de doctorat, Institut National Polytechnique de Toulouse, 272p.

[39] Adon, M.P. (2013). Variations spatiale et saisonnière du phytoplancton de la retenue d'eau d'adzopé (côte d'ivoire) composition, structure, biomasse et production primaire. Thèse de doctorat, Université de Nangui-Abrogoua, Côte d'Ivoire.
[40] Ouattara, A., Podoor, N., Gourène, G. (2001). Études préliminaires de la distribution spatio-temporelle du phytoplancton dans un système fluvio-lacustre africain (Bassin Bia; Côte d'lvoire). Hydroécologie Appliquée, 13, 113-132.

[41] Fonge, A., Chuyong, B., Tening, A., Fobid, A., Numbisi, N. (2013). Seasonal occurrence, distribution and diversity of phytoplankton in the Douala Estuary, Cameroon. African J. Aquat. Sci, 38, 123-133.

[42] Silva-Bedoya, L.M., Ramírez-Castrillón, M., OsorioCadavid, E. (2014). Yeast diversity associated to sediments and water from two Colombian artificial lakes. Brazilian J. Microbiol. 45, 135-142.

[43] Tundisi, J.G., Matsumura-Tundisi, T., Abe, D.S. (2007). Climate monitoring before and during limnological studies: a needed integration. Braz. J. Biol, 67, 795-796.

[44] Tundisi, J.G., Tundisi, T.M. (2012). Limnology. CRC Press.

[45] Brogueira, J.M., Oliveira, M., Cabeçadas, G. (2010). Phytoplankton community structure defined by key environmental variables in Tagus estuary,Portugal. Mar. Environ.Res, 64, 616.

[46] Bonilla, S., Villeneuve, V., Vincent, W.F. (2005). Benthic and planktonic algal communities in a high arctic lake: pigment structure and contrasting responses to nutrient enrichment. J. Phycol, 41, 1120-1130.

[47] Costa, L.S., Huszar, V.L., Ovalle, A.R. (2009). Phytoplankton functional groups in a tropical estuary: hydrological control and nutrient limitation. Estuar. Coasts,32(3), 508-521.

[48] Dalu, T., Taylor, J., Richoux, N., Froneman, W. (2015). A re-examination of the type material of Entomoneis paludosa (W Smith ) Reimer and its morphology and distribution in African waters. Fottea, Olomouc, 15, 11-25.

[49] Bahls, 1. (2012): Entomoneis paludosa. In Diatoms of the United States. http://westerndiatoms.colorado.edu/ taxa/species.

[50] Houari, A. (2009). République algérienne démocratique et populaire. Hassiba ben bouali chlef. Master Thesis, Université Hassiba Ben Bouali Chlef, Algérie.

[51] Descy, J.P., Darchambeau, F., Lambert, T., StoynevaGaertner, M.P., Bouillon, S., Borges, A.V. (2017). Phytoplankton dynamics in the Congo River. Freshw. Biol. $62,87-101$. 
Annexe

Table 5 : List of species per group Species

\begin{tabular}{|c|c|c|c|c|c|c|c|}
\hline Groups & Species & Groups & Species & Groups & Species & Groups & Species \\
\hline Group1 & Anabaena spiroides & Group3 & Diatoma mesodon & Group6 & Navicula phyllepta & Group9 & Gyrosigma fasciola \\
\hline Group1 & Asterionella sp. & Group3 & Hantzschia amphioxys & Group6 & Bacillaria sp. & Group9 & Tetraedron minimum \\
\hline Group1 & Closterium acutum & Group3 & Microcystis aeruginosa & Group7 & Monoraphidium contortum & Group9 & Euglena geniculata \\
\hline Group1 & Coelastrum microporum & Group3 & Encyonema silesiacum & Group7 & Scenedesmus sp. & Group9 & Euglena gracilis \\
\hline Group1 & Coscinodiscus lineatus & Group3 & Navicula reinhardtii & Group7 & Anomoeonis serians & Group 10 & Pandorina morum \\
\hline Group1 & Cymbella turgidula & Group3 & Navicula yarrensis & Group7 & Stephanodiscus sp. & Group 10 & Nitzschia linearis \\
\hline Group1 & Gomphonema clavatum & Group3 & Phacus succicus & Group7 & Phacus orbicularis & Group 10 & Stigeoclonium sp. \\
\hline Group1 & Prestauroneis protracta & Group3 & Pleurosigma delicatulum & Group7 & Crucigenia crucifera & Group 10 & Oedogonium sp. \\
\hline Group1 & Lyngbya martensiana & Group3 & Scenedesmus obtusus & Group7 & Stephanodiscus hantzschii & Group 10 & Euglena sp. \\
\hline Group1 & Merismopedia punctata & Group3 & Selenastrum sp. & Group7 & Navicula distans & Group10 & Stephanodiscus rotula \\
\hline Group1 & Monoraphidium sp. & Group3 & Nitzschia nana & Group7 & Surirella hybrida & Group 10 & Nitzschia closterium \\
\hline Group1 & Oocystis sp. & Group4 & Diploneis didyma & Group7 & Surirella fastuosa & Group 10 & Phacotus lenticularis \\
\hline Group1 & Pediastrum boryanum & Group4 & Microspora sp. & Group7 & Pinnularia lata & Group 10 & Gyrosygma sp. \\
\hline Group1 & Pediastrum tetras & Group4 & Nitzschia pellucida & Group7 & Euglena oxyuris & Group 10 & Microcystis sp. \\
\hline Group1 & Pinnularia dactylus & Group4 & Pinnularia pulchella & Group7 & Nitzschia circumsuta & Group 10 & Surirella sp. \\
\hline Group1 & Pinnularia gigas & Group4 & Staurastrum pingue & Group7 & Synedra acus & Group 10 & Aulacoseira granulata \\
\hline Group1 & Pinnularia limosa & Group4 & Trachelomonas klebsi & Group7 & Anabaena affinis & Group10 & Navicula sp. \\
\hline Group1 & Pleurosigma formosum & Group4 & Tryblionella debilis & Group7 & Closterium sp. & Group10 & Iconella capronii \\
\hline Group1 & Pleurosigma rigidum & Group4 & Ulnaria ulna & Group7 & Mastogloia smithii & Group 10 & Coscinodiscus sp. \\
\hline Group1 & Scenedesmus dimorphus & Group4 & Campylodiscus fastuosus & Group7 & Amphora ovalis & Group 10 & Planktolyngbya sp. \\
\hline
\end{tabular}


International Journal of Environment, Agriculture and Biotechnology, 5(3)

May-Jun, 2020 / Available: https://ijeab.com/

\begin{tabular}{|c|c|c|c|c|c|c|c|}
\hline Group1 & Scenedesmus granulatus & Group4 & Lepocinclis ovum & Group7 & Epithémia sp. & Group 10 & Entomoneis alata \\
\hline Group1 & Scenedesmus serratus & Group4 & Rhizoclonium tortuosum & Group7 & Pleurosygma sp. & Group 10 & Aulacoseira sp. \\
\hline Group1 & Scrippsiella sp. & Group4 & Asterococcus sp. & Group7 & Trachelomonas superba & Group 10 & Lyngbya sp. \\
\hline Group1 & Selenastrum bribraianum & Group4 & Pinnularia borealis & Group7 & Stephanopyxis palmeriana & Group 10 & Cyclotella sp. \\
\hline Group1 & Staurastrum cingulum & Group4 & Eunotia sepentina & Group7 & Placoneis amphibola & Group 10 & Nitzschia sp. \\
\hline Group1 & Staurastrum dilatatum & Group4 & Eunotia sp. & Group7 & Phacus longicauda & Group10 & Pinnunavis elegantoides \\
\hline Group1 & Staurastrum muricatum & Group4 & Kirchneriella irregualis & Group7 & Achnanthès sp. & Group10 & Cerataulina bicornis \\
\hline Group1 & Staurastrum setigerum & Group4 & Phacus gigas & Group7 & Anomoeoneis sp. & Group10 & Surirella robusta \\
\hline Group1 & Terpsinoe brebissonii & Group4 & Navicula radiosa & Group8 & Pinnularia dactylus & Group 10 & Eudorina elegans \\
\hline Group1 & Tetracystis chlorococcoides & Group4 & Licmophora abreviata & Group8 & Eudorina sp. & Group 10 & Entomoneis paludosa \\
\hline Group1 & Tetraedron triangulare & Group4 & Gonphonema sp. & Group8 & Mougeotia scalaris & & \\
\hline Group1 & Trachelomonas bacillifera & Group5 & Spirogyra sp. & Group8 & Chroococus sp. & & \\
\hline Group1 & Tribonema vulgare & Group5 & Spirulina major & Group8 & Navicula peregrinopsis & & \\
\hline Group1 & Triceratium castellatum & Group5 & Chaetoceros sp. & Group8 & Cymbella mexicana & & \\
\hline Group1 & Anabaenopsis circularis & Group5 & Nitzschia palea & Group8 & Plagiotropis lepideptora & & \\
\hline Group2 & Cosmarium punctulatum & Group5 & Eunotia pectinalis & Group8 & Coscinodiscus centralis & & \\
\hline Group2 & Tabularia sp. & Group5 & Pseudo-Nitzschia sp. & Group8 & Cocconeis placentula & & \\
\hline Group2 & Lepocinclis marssonii & Group5 & Cosmarium sp. & Group8 & Lyngbya majuscula & & \\
\hline Group2 & Ulotrix sp. & Group5 & Caloneis sp. & Group8 & Bacillaria pascillifer & & \\
\hline Group2 & Caloneis undulata & Group5 & Pinnularia macilenta & Group8 & Nitzschia scalaris & & \\
\hline Group2 & Campylodiscus simulans & Group5 & Cymbella cuspida & Group8 & Closterium lunula & & \\
\hline Group2 & Closterium lanceolatum & Group5 & Cymbella silesiaca & Group8 & Dictyosphaerium sp. & & \\
\hline Group2 & Crucigenia quadrata & Group5 & Pediastrum sp. & Group8 & Synedra sp. & & \\
\hline Group2 & Crucigenia rectangularis & Group5 & Phacus caudatus & Group8 & Actinastrum hantzschii & & \\
\hline Group2 & Fragilaria vaucheria & Group5 & Denticula sp. & Group8 & Euglena acus & & \\
\hline Group2 & Hantzschia sp. & Group5 & Closterium closteroides & Group8 & Euglena allorgei & & \\
\hline
\end{tabular}


International Journal of Environment, Agriculture and Biotechnology, 5(3)

May-Jun, 2020 / Available: https://ijeab.com/

\begin{tabular}{|c|c|c|c|c|c|}
\hline Group2 & Lyngbya rigidula & Group5 & Navicula blanda & Group8 & Alexandrium tamarense \\
\hline Group2 & Mougeotia sp. & Group5 & Nitzschia obtusa & Group8 & Tetraplektron torsum \\
\hline Group2 & Nitzschia gracilis & Group5 & Caloneis silicula & Group8 & Diploneis sp. \\
\hline Group2 & Nitzschia heufleuriana & Group5 & Euglena tripteris & Group8 & Cocconeis sp. \\
\hline Group2 & Oscillatoria nigoviridis & Group5 & Selenastrum gracile & Group8 & Synechocystis sp. \\
\hline Group2 & Phacus helikoides & Group5 & Nitzschia vermicularis & Group8 & Entomoneis sp. \\
\hline Group2 & Pinnularia cardinalis & Group5 & Pinnularia major & Group8 & Pleurosigma salinarum \\
\hline Group2 & Pleurotaenium sp. & Group5 & Microcystis wesenbergii & Group8 & Melosira nummuloides \\
\hline Group2 & Scenedesmus verrucosus & Group5 & Pinnularia viridis & Group8 & Phacus sp. \\
\hline Group2 & Staurastrum avicula & Group5 & Trachelomonas oblonga & Group8 & Terpsinoe musica \\
\hline Group2 & Tetracystis algae & Group5 & Hyalotheca sp. & Group9 & Coscinodiscus lacustris \\
\hline Group3 & Ceratium hirundinella & Group5 & Eunotia serra & Group9 & Gomphonema parvalum \\
\hline Group3 & Caloneis schumanniana & Group5 & Nitzschia panduriformis & Group9 & Pinnularia sp. \\
\hline Group3 & Fragilaria sp. & Group5 & Rhopalodia gibba & Group9 & Coscinodiscus wailesii \\
\hline Group3 & Gyrosigma scalproides & Group6 & Trachelomonas caudata & Group9 & Neidium sp. \\
\hline Group3 & Lepocinclis sp. & Group6 & Nitzschia intermedia & Group9 & Diatoma sp. \\
\hline Group3 & Navicula protracta & Group6 & Campylodiscus sp. & Group9 & Oscillatoria lacustris \\
\hline Group3 & Nitzschia triblyonella & Group6 & Ulothryx zonata & Group9 & Stigeoclonium subsecundum \\
\hline Group3 & Synechococcus maximus & Group6 & Gomphoneis sp. & Group9 & Phacus contortus \\
\hline Group3 & Tabellaria floculosa & Group6 & Navicula amphibola & Group9 & Stephanodiscus niagarae \\
\hline Group3 & Tetracystis sp. & Group6 & Rhopalodia musculus & Group9 & Pinnularia interrupta \\
\hline Group3 & Trachelomonas globularis & Group6 & Tabellaria sp. & Group9 & Gyrosigma attenuatum \\
\hline Group3 & Trachelomonas hispida & Group6 & Plagiotropis sp. & Group9 & Mallomonas sp. \\
\hline Group3 & Trachelomonas sp. & Group6 & Trachelomonas armata & Group9 & Cyclotella radiosa \\
\hline Group3 & Volvox sp. & Group6 & Tryblionella angustata & Group9 & Chaetoceros neogracilis \\
\hline Group3 & Merismopedia sp. & Group6 & Closterium gracile & Group9 & Nitzschia reversa \\
\hline
\end{tabular}


International Journal of Environment, Agriculture and Biotechnology, 5(3)

May-Jun, 2020 / Available: https://ijeab.com/

$\begin{array}{llllll}\text { Group3 } & \text { Spirulina subsalsa } & \text { Group6 } & \text { Closteriopsis longissimum } & \text { Group9 } & \text { Craticula cuspidata } \\ \text { Group3 } & \text { Lyngbya giganteum } & \text { Group6 } & \text { Cerataulinasp. } & \text { Group9 } & \text { Closterium venus } \\ \text { Group3 } & \text { Pediastrum duplex } & \text { Group6 } & \text { Gomphonema intricatum } & \text { Group9 } & \text { Gyrosigma accuminatum } \\ \text { Group3 } & \text { Oscillatoria limosa } & \text { Group6 } & \text { Denticula pelagica } & \text { Group9 } & \text { Amphora pediculus } \\ \text { Group3 } & \text { Ceratium sp. } & \text { Group6 } & \text { Gyrosigma hyppocampus } & \text { Group9 } & \text { Nitzschia sigma } \\ \text { Group3 } & \text { Epithemia argus } & \text { Group6 } & \text { Pleurosigma estuarii } & \text { Group9 } & \text { Lyngbya limnetica }\end{array}$

